\title{
KEEFEKTIFAN MEDIA AUDIO VISUAL SEBAGAI KREATIVITAS GURU SEKOLAH DASAR DALAM MENUMBUHKAN KETERAMPILAN MENULIS PUISI SISWA
}

\author{
Arum Tri Lestari, Mudzanatun, Aries Tika Damayani \\ arumjepara22@gmail.com, mudzanatun@gmail.com, afinobiologi@yahoo.com \\ PGSD, Universitas PGRI Semarang
}

\section{THE EFFECTIVENESS OF AUDIO VISUAL MEDIA TOWARDS STUDENTS' POETRY WRITING SKILL ASA CREATIVE TEACHER'S PRODUCT IN ELEMENTARY SCHOOL}

\begin{abstract}
The purpose of this study is to determine the effectiveness of the use of audio-visual media towars the poetry writing skill for students in 5th grade in Mororejo 2 Elementary School. This research is a quantitative research, and was implemented during three meetings for 70 minutes long in each meeting. The data was obtained using documentation, testing, interviews, and questionnaires. The analysis consisted of two stages. The first stage was a test of normality and the second stage was with normality test and pretest-posttest comparisons ( $t$-test). The result showed that the use of audio-visual media is effective to the skill of writing poetry for students of 5 th grade, Mororejo 2 Elementary School.
\end{abstract}

Keyword: poetry writing skill, audio-visual media

Revised date: 22 Juli 2017

Accepted date: 18 September 2017

\section{Pendahuluan}

Bangsa Indonesia memiliki bahasa persatuan yaitu bahasa Indonesia.Oleh karena itu, sejak kecil selain diajarkan bahasa ibu, anak biasanya juga diajarkan menggunakan Bahasa Indonesia.Pembelajaran Bahasa Indonesia dibangku sekolah dimulai dari tingkat sekolah dasar. Di sekolah dasar mata pelajaran bahasa Indonesia diajarkan dari kelas I sampai VI. Sebagian besar beranggapan bahwa Bahasa Indonesia merupakan mata pelajaran yang paling mudah daripada yang lainnya.Karena tidak ada proses berhitung yang rumit. Padahal tidak demikian.Pembelajaran Bahasa Indonesia justru lebih sulit.Karena membutuhkan keterampilan-keterampilan yang harus dikuasai. Keterampilan yang ada pada mata pelajaran Bahasa Indonesia antara lain: mendengarkan, berbicara, membaca, dan menulis.

Beberapa keterampilanyang ada pada mata pelajaran Bahasa Indonesia diatas, berdasarkan wawancara dengan guru kelas V SD N 2 Mororejo yaitu Bapak Setiadi, S.Pd, keterampilanyang masih sulit dicapai oleh siswa yaitu keterampilanmenulis. Dari jumlah 29 siswa hanya $60 \%$ yang mampu mencapai tingkat keterampilan sesuai Kriteria Ketuntasan Minimal (KKM).Khususnya dalam keterampilan menulis puisi.Walaupun guru telah menggunakan metode bank kata siswa tetap saja masih kesulitan dalam memahami materi.

Sufia Retti, dkk. (2013: 1) menyatakan Pembelajaran menulis merupakan sesuatu yang cenderung dianggap paling sulit oleh siswa termasuk menulis puisi. Menulis puisi merupakan salah satu bentuk apresiasi sastra yang harus dikuasai siswa". Berdasarkan pendapat di atas dapat disimpulkan bahwa pembelajaran Bahasa Indonesia khususnya menulis merupakan keterampilanyang sulit dikuasai siswa. Berdasarkan hasil wawancara juga menunjukkan bahwa walaupun gurutelah menggunakan metode bank kata, hasil belajar siswa tetap belum memuaskan. Hal ini juga bisa diakibatkan karena dalam menulis puisi, anak harus memiliki imajinasi dan kreativitas.Sehingga dalam pembelajaran menulis puisi guru harus mampu memunculkan dan mengembangkan ide atau imajinasi siswa yang berkaitan dengan tema yang sedang dipelajari.

Berdasarkan permasalahan yang terjadi peneliti dapat menyimpulkan bahwa guru sudah kreatif karena telah menggunakan metode bank kata, namun hanya belum efektif dalam pelaksanaan 
kegiatan pembelajarannya.Selain itu, kurangnya kreativitas guru dalam mengembangkan media pembelajaran yang hendak digunakan dalam mengajar.Sehingga kompetensi pembelajaran belum tercapai oleh siswa dengan maksimal.

Mengingat bahwa siswa sekolah dasar ialah masa dimana anak masih suka bermain dan lebih senang serta mudah memahami pembelajaran apabila pembelajaran yang dilakukan bersifat kongkret. Sehingga dibutuhkan suatu inovasi pembelajaran yang dapat membantu guru dalam menyampaikan materi dan memudahkan siswa dalam memahami materi pembelajaran. Inovasi pembelajaran dapat dilakukan melalui berbagai variasi terhadap penggunaan metode, media, model dan lain sebagainya yang mampu membantu guru dalam menyampaikan materi dengan kreatif. Berbagai variasi yang diterapkan nantinya akan memotivasi dan menarik perhatian siswa dalam pembelajaran. Sehingga siswa menjadi antusias, dan terfokus pada pembelajaran.

Permasalahan diatas dapat diberikan solusi dengan pemanfaatan media audio-visual. Media audio visual ialah suatu alat yang dapat membantu guru dalam menyampaikan materi pembelajaran kepada siswa yang tidak hanya berupa suara atau gambar saja, namun mencakup keduanya. Media audio visual dapat menampilkan gambar dan suara. Harapannya siswa menjadi tertarik dan memperhatikan pembelajaran dengan baik, siswa lebih kreatif dalam menyusun rangkaian kata khususnya dalam keterampilan menulis puisi dan nantinya dalam diri siswa akan muncul ide atau imajinasi serta rasa minat dalam menulis puisi. Sehingga dalam penelitian ini peneliti mengkaji mengenai keefektifan penggunaan media audio visual sebagai kreativitas guru dalam pembelajaran keterampilan menulis puisi siswa kelas V SD N 2 Mororejo Kendal.

Peneliti dalam penelitian ini merumuskan masalah yaitu bagaimanakah keefektifan media audio visual terhadap keterampilan menulis puisi siswa kelas V SD N 2 Mororejo Kendal?. Dengan tujuan penelitian untuk mengetahui sejauh mana keefektifan penggunaan media audio visual terhadap keterampilan menulis puisi siswa kelas V SD N 2 Mororejo Kendal.

\section{Kajian Pustaka}

\section{Keterampilan Menulis Puisi}

Kurikulum 2004 dan Kurikulum Tingkat Satuan Pendidikan(KTSP) menyebutkan bahwa "menulis merupakan keterampilan yangharus dibelajarkan dandikuasai oleh siswa. Dengan menulis, siswadapat menuangkan ide, pikiran, dan perasaan ke dalam bahasa tulis". Suatu ide, pikiran, perasaan dan gagasan seseorang dapat disampaikan tidak hanya dengan bahasa lisan, tetapi juga bahasa tulis. Bahasa tulis akan dikuasai seseorang dengan belajar menulis tentunya. Karena menulis merupakan suatu penyampaian ide, pikiran, perasaan maupun gagasan secara tertulis oleh seseorang agar dapat dipahami oleh pembaca.Jadi, seorang anak diajarkan menulis tujuannya agar anak memiliki keterampilan menulis dengan baik.

Hyland dalam Kastam Syamsi (2012: 2) menyatakan bahwa "menulis dipandang sebagai keterampilan berbahasa yang sangat penting yang harus dikuasai oleh siswa". Menulis dianggap sebagai keterampilan berbahasa yang sangat penting karena sebagai penyampai pesan, informasi, ide, gagasan, pikiran maupun perasaan seseorang selain dengan bahasa lisan. Sehingga keterampilan menulis harus dikuasai oleh seseorang agar penyampaian suatu pesan, informasi, gagasan, ide, pikiran maupun perasaan dapat optimal.

Berdasarkan pendapat diatas dapat disimpulkan bahwa menulis ialah suatu kegiatan penyampaian ide, gagasan, pikiran, maupun perasaan kepada orang lain dalam bentuk tulisan sehingga orang lain dapat memahami maksud penulis dengan membaca tulisan tersebut. Dalam kegiatan menulis tujuannya ialah menyampaikan pesan atau informasi kepada orang lain. Muatannya yaitu gagasan, ide, pikiran, dan perasaan.Medianya yaitu bahasa tulis.

Dwi Sulistyorini (2010:2) menyatakan "puisi adalah bentuk karya sastra yang mengungkapkan pikiran dan perasaan penyair secara imajinatif dan disusun dengan mengkonsentrasikan semua kekuatan bahasa dengan pengkonsentrasian struktur fisik dan struktur batinnya". Pendapat tersebut menyatakan bahwa puisi merupakan bentuk karya sastra yang dalam pembuatannya membutuhkan suatu imajinasi dan konsentrasi tinggi baik dari struktur fisik maupun batin dari kekuatan bahasa.

Dwi Sulistyorini (2010:1) menyatakan "menulis puisi merupakan salah satu keterampilan sastra yang harus dicapai siswa karena siswa akan memperoleh banyak manfaat dari kegiatan menulis puisi tersebut". Pendapat tersebut menyatakan bahwa dengan kegiatan menulis puisi, siswa 
akan memperoleh banyak manfaat. Oleh karena itu keterampilan menulis puisi harus dicapai oleh siswa.

Berdasarkan pendapat di atas dapat disimpulkan bahwa menulis puisi ialah salah satu bentuk karya sastra. Sehingga dalam menulis puisi, seseorang harus menguasai tentang karya sastra tersebut. Pembelajaran menulis puisi ialah salah satu pembelajaran yang dianggap sulit. Karena dalam karya sastra membutuhkan suatu imajinasi dan konsentrasi penulis baik batin maupun fisik.Sehingga hal inilah yang menjadi alasan mengapa pembelajaran menulis puisi dianggap sulit.Karena dalam pembelajarannya harus mampu menciptakan dan menjadikan siswa berpikir imajinasi dan terfokus pada karya sastra tersebut.

Menurut Dian Anggraini dkk. (2013: 1) "menulis puisi pada dasarnya mempunyai tujuan untuk meningkatkan daya pikir imajinasi siswa dan membentuk watak siswa. Siswa dapat mengekspresikan segala sesuatu yang ada pada pikirannya, berupa kata-kata yang dirangkai dalam sebuah karya sastra yang mempunyai makna yaitu puisi". Berdasarkan pernyataan di atas dapat disimpulkan bahwa manfaat dari keterampilan menulis puisi ialah seseorang dapat mengekspresikan dirinya tentang segala hal yang dipikirkannya terhadap sesuatu. Selain itu, juga dapat melatih kreativitas siswa dalam pengunaan bahasa yang tepat dalam menyampaikan ekspresinya. Karena dari tulisan dapat tercermin pikirannya.

Berdasarkan pernyataan di atas yang menyatakan bahwa keterampilan menulis puisi ialah keterampilan paling sulit. Sehingga memerlukan kreativitas guru dalam pembelajaran. Dimana guru harus mampu membantu siswa dalam berpikir kreatif. Maka guru memerlukan perencanaan pembelajaran yang inovatif dan kreatif. Sehingga siswa akan termotivasi untuk belajar menulis. Upaya yang dapat dilakukan guru diantaranya dengan penggunaan metode, model ataupun media pembelajaran yang mendukung pembelajaran dan tentu menarik perhatian siswa.

Dalam pembelajaran menulis biasanya guru hanya menekankan pada hasil dari menulis siswa. Tidak melihat dari proses dari kegiatan menulis tersebut. Sehingga dengan penggunaan media audio visual siswa tidak hanya akan diminta menulis tetapi juga ditunjukkan bagaimana menulis puisi yang sebenarnya, kata-kata dalam menulis itu diperoleh dari mana, apakah yang harus ditulis dan sebagainya.

Berdasarkan penelitian Azmusssya'ni, dkk (2014: 10-11) tentang keterampilan menulis dimana "evaluasi hasil yang dilaksanakan, yaitu menilai karangan siswa. Adapun indikator penilaian hasil yang digunakan dalam mengoreksi karangan siswa berjumlah lima butir. Kelima butir indikator tersebut, kesesuaian judul dengan isi; penggunaan ejaan dan tanda baca; menulis tegak bersambung; pilihan kata/diksi; dan kerapihan tulisan".

Berdasar pada penelitian di atas, peneliti dalam penelitian ini melakukan penilaian keterampilan menulis puisi dengan indikator meliputi: kesesuaian isi puisi dengan judul dan tema yang telah ditentukan, pemilihan kata (diksi) yang digunakan siswa dalam menyusun puisi, penggunaan ejaan dan tanda baca dalam menyusun puisi, kerapian tulisan siswa dalam menuliskan puisi dan tingkat imajinasi siswa dalam berpikir kreatif.

\section{Media Audio Visual}

Azhar Arsyad (2014: 6) menyatakan bahwa "media pendidikan memiliki pengertian alat bantu pada proses belajar baik di dalam maupun di luar kelas". Dalam pendidikan media digunakan sebagai alat bantu guru dalam menyampaikan pembelajaran baik di dalam maupun di luar kelas. Hujair AH Sanaky (2013: 4) menyatakan bahwa "media pembelajaran adalah sarana atau alat bantu pendidikan yang dapat digunakan sebagai perantara dalam proses pembelajaran untuk mempertinggi efektivitas dan efisiensi dalam mencapai tujuan pengajaran". Pendapat tersebut menyatakan bahwa media sebagai perantara pembelajaran dari guru kepada siswa agar siswa dapat dengan mudah mencapai tujuan pengajaran dengan efektif dan efisien.

Berdasarkan beberapa pendapat di atas dapat disimpulkan bahwa pengertian media pembelajaran adalah segala sesuatu (baik itu orang, alat, benda, dan sebagainya) yang dapat membantu guru dalam mengajar sehingga peserta didik dapat memahami pembelajaran dengan mudah serta mampu mencapai tujuan pembelajaran dengan optimal.

Menurut Hamalik dalam Azhar Arsyad (2014: 19) "pemakaian media pembelajaran dalam proses belajar mengajar dapat membangkitkan keinginan dan minat yang baru, membangkitkan 
motivasi dan rangsangan kegiatan belajar, dan bahkan membawa pengaruh-pengaruh psikologi terhadap siswa".

Media pembelajaran dianggap penting karena dengan menggunakan media maka akan memudahkan siswa dalam memahami materi karena dengan bantuan media dapat menyamakan persepsi siswa yang berbeda satu sama lain, mengkonkritkan konsep-konsep yang abstak, mampu menghadirkan objek-objek yang besar maupun berbahaya dalam pembelajaran di kelas, serta dapat memperlihatkan suatu proses tertentu yang terlalu cepat atau lambat dalam kerjanya. Dengan demikian adanya suatu media menjadi sangat penting dalam setiap pembelajaran. Kriteria pemilihan media yang harus diperhatikan menurut Azhar Arsyad (2014: 74) ialah: 1) Sesuai dengan tujuan yang ingin dicapai, 2) Tepat untuk mendukung isi pelajaran yang sifatnya fakta, konsep, prinsip, atau generalisasi, 3) Praktis, luwes dan bertahan, 4) Guru terampil menggunakannya, 5) Pengelompokan sasaran dan 6) Mutu teknis.

Dick dan Carey dalam Arief S. Sadiman, dkk.(2014: 86) menyebutkan bahwa "disamping kesesuaian dengan tujuan perilaku belajarnya, setidaknya masih ada empat faktor lagi yang perlu dipertimbangkan dalam pemilihan media".Pendapat tersebut menyatakan bahwa pertimbangan memilih media selain kesesuaian dengan tujuan belajar yaitu antara lain: ketersediaan sumber di sekitar, apakah media yang hendak digunakan memerlukan dana, tenaga maupun fasilitas lain, faktor keluwesan, kepraktisan maupun ketahanan dari media yang digunakan, serta efektivitas biaya yang diperlukan media.

Berdasarkan uraian di atas dapat disimpulkan bahwa kriteria dalam memilih media pembelajaran yang paling penting ialah disesuaikan dengan tujuan pembelajaran yang akan dicapai. Karena maksud dari digunakannya media pembelajaran ialah untuk membantu guru dalam memudahkan siswa memahami pembelajaran dengan efektif dan efisien.Berdasarkan pada latar belakang dan uraian yang telah dipaparkan di atas bahwa pembelajaran Bahasa Indonesia khususnya keterampilan menulis puisi anak ialah termasuk dalam kategori sulit. Maka oleh peneliti, mengkaji permasalahan dengan menggunakan alternatif tindakan yaitu dengan penggunaan media audio visual.

Menurut Sapto Haryoko (2009: 3) "Media audio-visual adalah media penyampai informasi yang memiliki karakteristik audio (suara) dan visual (gambar). Jenis media ini mempunyai kemampuan yang lebih baik, karena meliputi kedua karakteristik tersebut". Pendapat tersebut menyatakan bahwa media audio visual yaitu wadah penyampai informasi yang memiliki dua karakter yaitu karakter audio berupa suara dan karakter visual yang berupa gambar. Sehingga media jenis ini dianggap memiliki kemampuan yang lebih baik dari yang lainnya.

Berdasarkan pendapat di atas dapat disimpulkan bahwa penggunaan media audio-visual akan sangat efektif karena adanya karakteristik suara dan gambar. Karena mengingat bahwa siswa SD termasuk dalam usia masa anak-anak yang masih suka bermain daripada belajar. Jadi seorang guru harus mampu menciptakan suatu pembelajaran yang menarik bagi siswa, yang membuat siswa tidak terpaksa dalam belajar. Namun karena keinginan siswa sendiri dalam memperhatikan pembelajaran. Penggunaan media audio-visual inilah siswa akan merasa tertarik dalam belajar karena efek gambar dan suara yang diciptakan dalam media. Media yang diciptakan guru pun harus sesuai dengan materi pembelajaran yang diajarkan. Media audio-visual antara lain dapat berupa televisi, film, video VCD dan sound slide.

Peneliti dalam penelitian ini menggunakan aplikasi flipbook maker sebagai sarana untuk berkreativitas. Aplikasi flipbook maker adalah aplikasi komputer yang berupa lembaran-lembaran kertas disusun runtut sesuai dengan materi yang diajarkan. Flipbook maker dapat digunakan sebagai media penyampai pesan pembelajaran dengan menampilkan gambar dan suara. Dimana aplikasi ini akan menunjukkan seolah-olah buku elektronik yang dapat dibolak-balik layaknya buku pada umumnya. Hal inilah yang akan menarik bagi siswa. Berikut cara mendesain Flipbook:

a. Pertama, flipbook hanya berisi lembaran-lembaran kertas kosong yang siap diisi pesan pembelajaran

b. Guru menyiapkan materi pembelajaran yang akan disajikan dalam flipbook maker

c. Masukan pesan-pesan pembelajaran yang telah disiapkan sebelumnya baik berupa gambar, teks, grafik, bagan dan lain-lain ke dalam lembaran-lembaran yang ada dalam aplikasi. Materi yang disajikan pun harus sesuai dengan tujuan pembelajaran yang hendak dicapai. 
Keefektifan Media Audio Visual Sebagai Kreativitas Guru Sekolah Dasar Terhadap Keterampilan Menulis Puisi Siswa (Arum Tri Lestari, Mudzanatun, Aries Tika Damayani)

d. Setelah selesai proses edit, proses selanjutnya yaitu simpan file. Dan file siap disajikan di depan kelas.

\section{METODE PENELITIAN}

Penelitian ini dilaksanakan pada siswa kelas V SD Negeri 2 Mororejo, Kecamatan Kaliwungu, Kabupaten Kendal. Penelitian ini dilaksanakan pada semester 2 tahun pelajaran 2016/2017 bulan Februari. Pertemuan dilakukan 3 kali dimana setiap pertemuan selama 70 menit. Pertemuan pertama dilaksanakan pada hari Sabtu 25 Februari 2017, pertemuan kedua pada Senin 27 Februari 2017 dan pertemuan ketiga pada Selasa 28 Februari 2017. Variabel bebas dalam penelitian ini adalah media audio-visual.Variabel terikat dalam penelitian ini adalah keterampilan menulis puisi siswa kelas V SD Negeri 2 Mororejo. Metode penelitian yang digunakan dalam penelitian ini adalah metode eksperimen. Dengan Pre Experimental Design dengan jenis One Group PretestPosttest Design.

Populasi dalam penelitian ini adalah siswa SD N 2 Mororejo tahun pelajaran 2016/2017. Penelitian ini menggunakan penelitian populasi, yaitu populasi penelitian sekaligus sebagai sampel penelitian, yaitu siswa SD N 2 Mororejo sampel dalam penelitian ini terdapat satu kelas yaitu kelas V SD N 2 Mororejo dengan jumlah 25 siswa. Teknik sampling yang digunakan dalam penelitian ini adalah non probability sampling dengan jenis sampling jenuh. Sampling jenuh adalah teknik pengambilan sampel dimana semua anggota populasi digunakan sebagai sampel. Teknik pengumpulan data, meliputi:

1. Dokumentasi

Dokumetasi dalam peneltian ini bewujud daftar nama siswa kelas V SD N 2 Mororejo, daftar hasil belajar serta dokumentasi foto saat proses pembelajaran.

2. Tes

Pengumpulan data dengan tes ini digunakan peneliti unuk mengukur keterampilan menulis puisi dengan menggunakan media audio-visual. Tes yang digunakan dalam penelitian ini adalah uraian yang diberikan di awal pertemuan pertama dan di akhir pembelajaran pada pertemuan ketiga.

3. Wawancara

Teknik pengumpulan data ini dilakukan dengan memberikan sejumlah pertanyaan baik pada guru dan beberapa siswa yang dijadikan narasumber terkait penelitian tentang keterampilanmenulis puisi siswa kelas V SD N 2 Mororejo. Wawancara ini dilakukan untuk mendapatkan data-data yang diperlukan oleh peneliti dalam penelitian yang dilakukannya.

4. Angket

Instrumen ini digunakan untuk melakukan uji validasi terhadap media dan materi yang digunakan oleh peneliti dalam penelitian ini. Validasi media dimaksudkan untuk mengetahui kelayakan media sebelum digunakan dalam penelitian dan validasi materi dimaksudkan untuk mengetahui kesesuaian muatan materi dengan indikator yang akan dicapai dengan media yang disajikan dalam penelitian. Pengumpulan data menggunakan angket ini dilakukan sebelum penelitian oleh penguji ahli media dan ahli materi. Instrumen penelitian yang digunakan dalam pengumpulan data penelitian ini ialah alat dokumentasi, kisi-kisi soal tes, pedoman wawancara, dan lembar angket.

Analisis data dalam suatu penelitian merupakan bagian yang sangat penting, karena dengan adanya analisis data masalah dalam penelitian tersebut dapat diketahui jawabannya. Dalam langkah memilih pendekatan penelitian, telah dikemukakan beberapa desain eksperimen diantaranya telah disertai rumus atau analisis datanya. Untuk menganalisis, hasil eksperimen yang menggunakan pretest dan posttest one group design. Pada tahap awal analisis data dilakukan dengan uji normalitas. Sedangkan, pada tahap akhir terdapat uji normalitas, dan uji banding pretest dan posttest.

\section{HASIL PENELITIAN DAN PEMBAHASAN}

Deskripsi data diperoleh dari kelas eksperimen yang telah diamati baik dari sebelum dan sesudah diberi perlakuan berupa penggunaan media audio visual. Deskripsi data yang diperoleh sebelum perlakuan adalah nilai pretest. Deskripsi data yang diperoleh setelah perlakuan adalah nilai posttest. Berdasarkan KKM mata pelajaran Bahasa Indonesia kelas V SD N 2 Mororejo yang telah 
ditetapkan yaitu 75. Hal ini dapat dinyatakan dengan dua kategori yaitu $<75$ dinyatakan tidak tuntas dan $\geq 75$ dinyatakan tuntas. Selanjutnya dapat dinyatakan dalam bentuk tabel berikut:

Tabel 1

Distribusi Frekuensi Nilai Pretest

\begin{tabular}{ccc}
\hline Nilai & $\begin{array}{c}\text { Siswa yang } \\
\text { memperoleh nilai }\end{array}$ & Persentase \\
\hline $55-59$ & 3 & $12 \%$ \\
\hline $60-64$ & 2 & $8 \%$ \\
\hline $65-69$ & 4 & $16 \%$ \\
\hline $70-74$ & 6 & $24 \%$ \\
\hline $75-79$ & 5 & $20 \%$ \\
\hline $80-84$ & 5 & $20 \%$ \\
\hline Jumlah & 25 & $100 \%$ \\
\hline
\end{tabular}

Berdasarkan tabel 1 di atas, menunjukkan bahwa jumlah siswa yang memperoleh nilai 5559 sejumlah 3 siswa, nilai 60-64 sejumlah 2 siswa, nilai 65-69 sejumlah 4 siswa, nilai 70-74 sejumlah 6 siswa, nilai 75-79 sejumlah 5 siswa dan nilai 80-84 sejumlah 5 siswa. Berdasarkan data tersebut dapat disimpulkan bahwa jumlah siswa yang memperoleh nilai tuntas sesuai Kriteria Ketuntasan Minimum (KKM) yaitu $\geq 75$ ialah hanya sejumlah 10 siswa.Sehingga ada sejumlah 15 siswa yang belum mencapai ketuntasan minimum. Berikut disajikan data dalam bentuk diagram batang untuk memperjelas tabel 1 sebagai berikut:

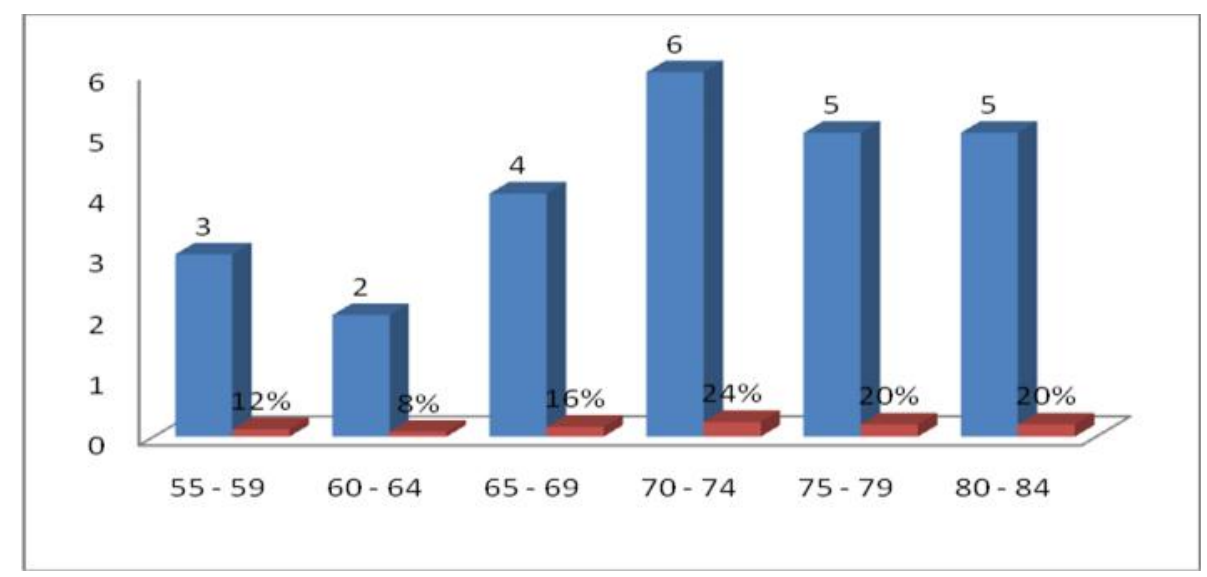

Gambar 1

Diagram Rekapitulasi Distribusi Frekuensi Nilai Pretest

Berdasarkan diagram rekapitulasi diatas menunjukkan bahwa dari jumlah siswa 25 persentase jumlah siswa yang memperoleh nilai 55-59 sebesar 12\% sejumlah 3 siswa, nilai 60-64 sebesar $8 \%$ sejumlah 2 siswa, nilai $65-69$ sebesar $16 \%$ sejumlah 4 siswa, nilai $70-74$ sebesar $24 \%$ sejumlah 6 siswa, nilai 75-79 sebesar 20\% sejumlah 5 siswa dan nilai 80-84 sebesar 20\% sejumlah 5 siswa. Sehingga dapat dinyatakan bahwa jumlah persentase siswa yang memperoleh nilai dibawah KKM (tidak tuntas) sebesar $60 \%$ sejumlah 15 siswa dan persentase siswa yang memperoleh nilai diatas KKM (tuntas) hanya 40\% sejumlah 10 siswa. Selanjutnya akan disajikan rekapitulasi nilai pretest dalam bentuk tabel dibawah ini: 
Keefektifan Media Audio Visual Sebagai Kreativitas Guru Sekolah Dasar Terhadap Keterampilan Menulis Puisi Siswa (Arum Tri Lestari, Mudzanatun, Aries Tika Damayani)

Tabel 2

Rekapitulasi Nilai Pretest

\begin{tabular}{lc}
\hline \multicolumn{2}{c}{ Kelas Eksperimen } \\
\hline Jumah Nilai & 1740 \\
\hline Rata-rata & 69,6 \\
\hline Nilai Terendah & 55 \\
\hline Nilai Tertinggi & 80 \\
\hline
\end{tabular}

Berdasarkan tabel 2 rekapitulasi nilai pretest, maka dapat dilihat bahwa dari 25 siswa ratarata nilai pretest pada kelas eksperimen yaitu 69,6 dengan batas kriteria ketuntasan minimum (KKM) diambil dari mata pelajaran Bahasa Indonesia yaitu 75. Nilai terendah 55 dan nilai tertinggi 80.Rata-rata hasil nilai pretest ini jelas tidak mencapai KKM yang sudah ditetapkan. Berdasarkan hasil nilai pretest yang belum mencapai KKM, selanjutnya dilakukan perlakuan dengan menggunakan media audio visual dalam kegiatan pembelajaran. Setelah pelaksanaan kegiatan pembelajaran dengan diberi perlakuan menggunakan media audio visual kemudian siswa diberi soal posttest. Selanjutnya dapat dinyatakan dalam bentuk tabel berikut:

Tabel 3

Distribusi Frekuensi Nilai Posttest

\begin{tabular}{ccc}
\hline Nilai & $\begin{array}{c}\text { Siswa yang } \\
\text { memperoleh nilai }\end{array}$ & Persentase \\
\hline $65-70$ & 7 & $28 \%$ \\
\hline $71-76$ & 1 & $4 \%$ \\
\hline $77-82$ & 5 & $20 \%$ \\
\hline $83-88$ & 4 & $16 \%$ \\
\hline $89-94$ & 4 & $16 \%$ \\
\hline $95-100$ & 4 & $16 \%$ \\
\hline Jumlah & 25 & $100 \%$ \\
\hline
\end{tabular}

Berdasarkan tabel 3 di atas, menunjukkan bahwa jumlah siswa yang memperoleh nilai 6570 sejumlah 7 siswa, nilai 71-76 sejumlah 1 siswa, nilai 77-82 sejumlah 5 siswa, nilai 83-88 sejumlah 4 siswa, nilai 89-94 sejumlah 4 siswa dan nilai 95-100 sejumlah 4 siswa. Berdasarkan data tersebut dapat disimpulkan bahwa jumlah siswa yang memperoleh nilai tuntas sesuai Kriteria Ketuntasan Minimum (KKM) yaitu 275 ialah hanya sejumlah 18 siswa.Sehingga ada sejumlah 7 siswa yang belum mencapai ketuntasan minimum. Berikut disajikan data dalam bentuk diagram batang untuk memperjelas tabel 5 sebagai berikut:

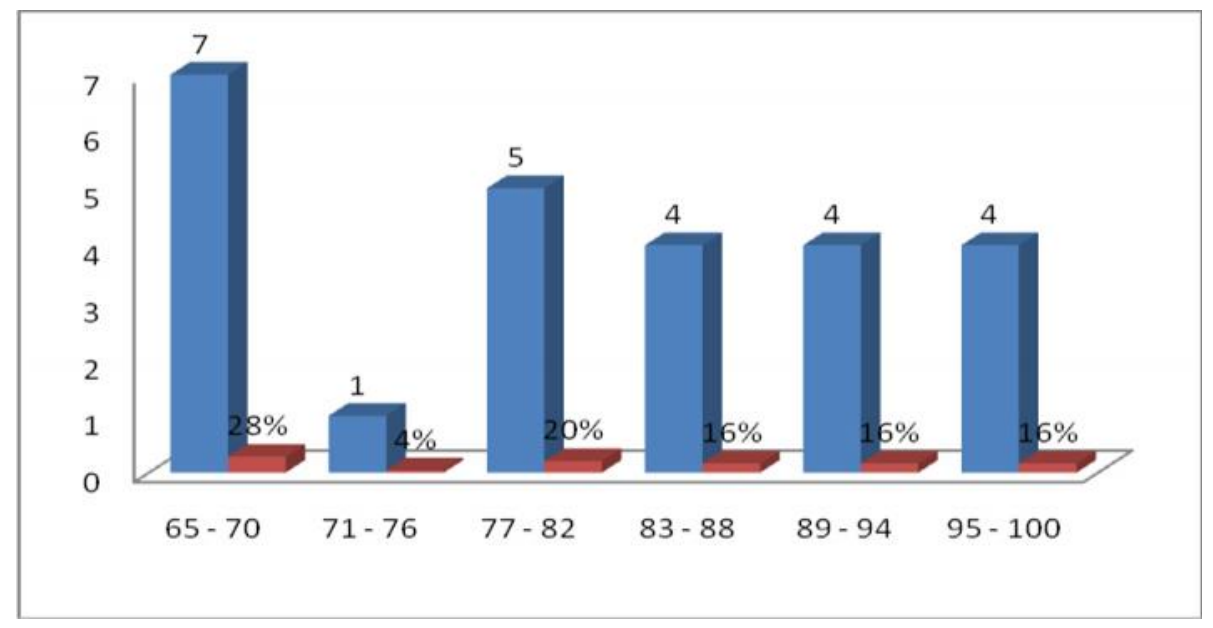

Gambar 2

Diagram Rekapitulasi Distribusi Frekuensi Nilai Posttest 
Berdasarkan gambar 2, di atas menunjukkan bahwa dari jumlah siswa 25 persentase jumlah siswa yang memperoleh nilai 65-70 sebesar 28\% sejumlah 7 siswa, nilai 71-76 sebesar $4 \%$ sejumlah 1 siswa, nilai $77-82$ sebesar $20 \%$ sejumlah 5 siswa, nilai $83-88$ sebesar $16 \%$ sejumlah 4 siswa, nilai 89-94 sebesar 16\% sejumlah 4 siswa dan nilai $95-100$ sebesar 16\% sejumlah 4 siswa. Sehingga dapat dinyatakan bahwa jumlah persentase siswa yang memperoleh nilai dibawah KKM (tidak tuntas) sebesar $28 \%$ sejumlah 7 siswa dan persentase siswa yang memperoleh nilai diatas KKM (tuntas) sebesar $72 \%$ sejumlah 18 siswa. Selanjutnya disajikan rekapitulasi nilai posttest dalam bentuk tabel dibawah ini:

Tabel 4

Rekapitulasi Nilai Posttest

\begin{tabular}{lc}
\hline \multicolumn{2}{c}{ Kelas Eksperimen } \\
\hline Jumah Nilai & 2030 \\
\hline Rata-rata & 81,2 \\
\hline Nilai Terendah & 65 \\
\hline Nilai Tertinggi & 95 \\
\hline
\end{tabular}

Berdasarkan tabel 4 rekapitulasi nilai posttest, maka dapat dilihat dari 25 siswa rata-rata nilai posttest pada kelas eksperimen yaitu 81,2 dengan batas ketuntasan minimal (KKM) diambil dari mata pelajaran Bahasa Indonesia yaitu 75. Nilai terendah 65 dan nilai tertinggi 95. Berdasarkan hasil nilai pretest dan posttest di atas dapat disimpulkan bahwa ada perbedaan keterampilan menulis puisi siswa sebelum diberi perlakuan dan sesudah diberi perlakuan menggunakan media audio visual. Hal ini dapat dilihat dari tabel berikut:

Tabel 5

Rekapitulasi nilai pretest dan posttest

\begin{tabular}{lcc}
\hline \multicolumn{1}{c}{ Data } & Pretest & Posttest \\
\hline Nilai terendah & 55 & 65 \\
\hline Nilai tertinggi & 80 & 95 \\
\hline Rata-rata & 69.6 & 81.2 \\
\hline Siswa yang tuntas & 10 & 18 \\
\hline Siswa yang tidak tuntas & 15 & 7 \\
\hline
\end{tabular}

Berdasarkan tabel 5 rekapitulasi di atas, dapat disimpulkan bahwa dari nilai pretest diperoleh nilai terendah 55, nilai tertinggi 80 , rata-rata nilai 69,6 , siswa yang tuntas hanya sejumlah 10 siswa dan siswa yang tidak tuntas sejumlah 15 siswa. Sedangkan, dari nilai posttest diperoleh nilai terendah 65 , nilai tertinggi 90, rata-rata nilai 81,2, siswa yang tuntas sejumlah 18 siswa dan siswa yang tidak tuntas sejumlah 7 siswa. Untuk memperjelas tabel 4.5, berikut disajikan data perbandingan nilai pretest dan posttest dalam bentuk diagram batang:

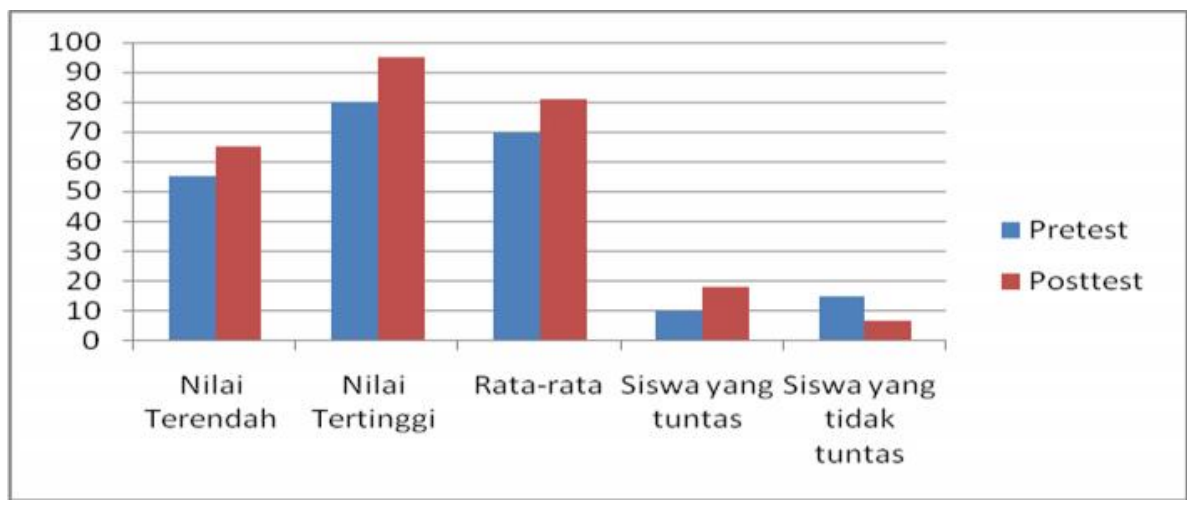

Gambar 3

Diagram Rekapitulasi Perbandingan Nilai Pretest dan Posttest 
Berdasarkan gambar 3 diagram rekapitulasi perbandingan nilai pretest dan posttest di atas, dapat disimpulkan bahwa terjadi peningkatan dari nilai pretest dan posttest terkait nilai terendah, nilai tertinggi, rata-rata nilai, sampai jumlah siswa yang tuntas. Sedangkan, siswa yang tidak tuntas terjadi penurunan.Hal ini menunjukkan bahwa kegiatan pembelajaran sebelum dan sesudah perlakuan ada perbedaan respon siswa sehingga keterampilan menulis puisi siswa menjadi meningkat.

Penelitian yang peneliti lakukan memperoleh data fakta bahwa penggunaan media audio visual sebagai perlakuan terhadap keterampilan menulis siswa lebih efektif dibandingkan dengan metode konvensional atau sebelum diberi perlakuan. Hal ini dibuktikan dengan perhitungan analisis data yang diperoleh peneliti dalam penelitian.Data diperoleh dari hasil nilai lembar soal pretest dan posttest yang telah dikerjakan siswa.Hasil nilai pretest diperoleh keterampilan menulis puisi siswa sebelum diberi perlakuan. Hasil nilai posttest diperoleh dari keterampilan menulis puisi siswa setelah diberi perlakuan berupa penggunaan media audio visual dalam kegiatan pembelajaran.

Analisis data diawali dari uji normalitas data awal yang diperoleh dari nilai pretest siswa. Uji ini untuk mengetahui apakah sampel yang digunakan berdistribusi normal.Berdasarkan hasil penelitian, menunjukkan bahwa rata-rata nilai pretest dari jumlah sampel 25 siswa yaitu 69,6. Setelah itu, dilanjutkan dengan analisis data akhir yang terdiri dari tiga uji, yaitu uji normalitas data dan uji banding pretest dan posttest (uji-t). Uji hipotesis yang pertama yaitu uji normalitas. Data pada uji ini diperoleh dari nilai posttest siswa. Uji ini untuk mengetahui apakah sampel yang digunakan berdistribusi normal. Berdasarkan hasil penelitian menunjukkan bahwa rata-rata nilai posttest dari jumlah sampel 25 siswa yaitu 81,2. Kriteria Ketuntasan Minimum (KKM) dari sekolah sudah menetapkan untuk mata pelajaran Bahasa Indonesia yaitu 75.

Uji hipotesis yang kedua yaitu uji banding pretest dan posttest (uji-t). Uji ini dilakukan untuk mengetahui seberapa besar perbandingan antara nilai posttest dan pretest, sehingga dapat diperoleh kesimpulan apakah penggunaan media audio visual efektif untuk meningkatkan keterampilan menulis puisi siswa. Berdasarkan hasil penelitian diperoleh data bahwa dengan $\mathrm{N}=25$ dan taraf signifikan $=5 \%$ diperoleh $t_{\text {hitung }}=6,170$ dan $t_{\text {tabel }}=2,064$. Karena $t_{\text {hitung }}>t_{\text {tabel, }}$, maka dapat disimpulkan bahwa uji t signifikan. Berdasarkan data hasil rata-rata nilai pretest dan posttest dimana hasil rata-rata nilai pretest $=69,6$ dan hasil rata-rata nilai posttest $=81,2$. Hal ini menunjukkan bahwa ada peningkatan sebesar 11,6 dari perbandingan hasil rata-rata nilai pretest dan posttest. Dengan demikian dapat disimpulkan bahwa penggunaan media audio visual lebih efektif dalam kegiatan pembelajaran keterampilan menulis puisi siswa jika dibandingkan dengan kegiatan pembelajaran sebelum menggunakan media audio visual.

\section{PEMBAHASAN}

Media audio visual ini digunakan dengan maksud agar siswa tidak jenuh dengan pembelajaran. Terlebih lagi pembelajaran Bahasa Indonesia yang dianggap mudah jadi terkadang beberapa siswa tidak memperhatikan pembelajaran dengan seksama.Penyajian materi yang tidak seperti biasanya atau konvensional lebih menarik bagi siswa untuk antusias dan memperhatikan pembelajaran. Penggunaan media audio visual dimaksudkan juga untuk meningkatkan imajinasi dan kreativitas siswa dalam menyusun sebuah puisi bebas. Hal ini bisa diperoleh siswa dari kedalaman materi dan animasi yang termuat di dalam media. Maka dari itu, sebelum media digunakan untuk media pembelajaran di sekolah telah terlebih dahulu dinilai oleh ahli materi sekaligus ahli media yang tidak lain ialah dosen pembimbing peneliti. Penilaian media menggunakan angket validasi untuk mengetahui apakah media telah layak digunakan terkait dengan kedalaman materi dan kelayakan media.Setelah dinyatakan layak oleh dosen pembimbing sebagai ahli materi dan ahli media maka media siap digunakan di sekolah.

Berdasarkan penelitian menunjukkan bahwa penggunaan media audio visual dalam kegiatan pembelajaran Bahasa Indonesia efektif untuk meningkatkan keterampilan menulis puisi siswa dibandingkan sebelum menggunakan media audio visual. Hal ini dibuktikan dengan hasil nilai pretest dan posttest dari jumlah sampel 25 siswa dimana nilai pretest siswa menunjukkan rata-rata 69,6 dan nilai posttest siswa menunjukkan rata-rata 81,2. Hasil tersebut menunjukkan bahwa ada peningkatan dari rata-rata nilai pretest dan posttest sebesar 11,6. Sehingga terbukti bahwa penggunaan media audio visual efektif terhadap keterampilan menulis puisi siswa di SD N 2 Mororejo Kendal. 
Hasil penelitian diatas relevan dengan penelitian yang dilakukan oleh Rahmah Nuzulia (2014) dengan judul Keefektifan Pendekatan Scientific Berbantuan Audio Visual terhadap Kompetensi Inti Tema Cita-citaku Siswa Kelas IV SDN Kertijayan 03 Pekalongan membuktikan bahwa terdapat peningkatan hasil belajar. Hal ini ditunjukkan dengan hasil uji $t$ dimana $t_{\text {hitung }}>t_{\text {tabel }}$ yakni 14,103>2,07 menunjukkan bahwa nilai thitung lebih besar $t_{\text {tabel }}$. Nilai posttest lebih besar sebesar 84,17 dibanding dengan pretest sebesar 68,63. Jadi ada perbedaan yang signifikan antara posttest dan pretest. Sehingga $85 \%$ siswa sudah mencapai ketuntasan belajar pada aspek psikomotorik dan afektif dengan kriteria minimal 2,66 (B-). Dengan demikian dapat disimpulkan bahwa melalui media audio visual dapat meningkatkan kualitas pembelajaran yang meliputi hasil belajar siswa.

Penelitian yang dilakukan oleh Akwab Firdaus (2016) dengan judul Penerapan Media Audio Visual pada hasil belajar matematika materi operasi hitung campuran kelas IV SD Negeri 02 Doro membuktikan bahwa terdapat perbedaan hasil belajar matematika setelah menggunakan penerapan media audio visual materi operasi hitung campuran kelas IV SD Negeri 02 Doro. Hal ini ditunjukkan dari hasil penelitian pada kelas eksperimen diketahui nilai rata-rata pretest adalah 74,00 sedangkan nilai rata-rata posttest adalah 93,20. Hasil ini diperkuat dengan perhitungan hipotesis menggunakan uji-t diperoleh hasil thitung $=7,456$ dengan $\mathrm{db}=\mathrm{N}-1=20-1=19$ dan taraf signifikan $5 \%$ diperoleh $t_{\text {tabel }}=2,093$. Karena $t_{\text {hitung }}>t_{\text {tabel }}$, maka $H_{0}$ ditolak. Sehingga hipotesis pada penelitian ini adalah diterima. Atas dasar penelitian tersebut maka hipotesis yang berbunyi ialah ada perbedaan hasil belajar matematika setelah menggunakan penerapan media audio visual materi operasi hitung campuran kelas IV SD Negeri 02 Doro.

Berdasarkan penelitian di atas membuktikan bahwa penggunaan media audio-visual terhadap pembelajaran matematika dapat meningkatkan hasil belajar siswa yang sangat signifikan. Dilihat dari hasil pretest dan posttest yang telah dilakukan peneliti, dimana rata-rata nilai pretest sebesar 74,00 dan posttest sebesar 93,20. Nilai pretest diperoleh dari hasil belajar siswa sebelum kelas diberi perlakuan. Dan nilai posttest diperoleh dari hasil belajar siswa setelah siswa diberi perlakuan dengan penggunaan media audio-visual dalam pembelajaran keterampilan menulis puisi. Dengan demikian dapat dinyatakan bahwa penggunaan media audio visual dapat efektif dalam membantu guru menyampaikan pembelajaran di kelas sehingga mampu mengoptimalkan ketercapaian tujuan pembelajaran dengan peningkatan hasil belajar siswa.

Penelitian yang dilakukan oleh Sugiarto (2014) dengan judul pengaruh bimbingan belajar dengan media audio visual terhadap kreativitas belajar siswa kelas X MAN I Demak Tahun Pelajaran 2013/2014 membuktikan bahwa hasil analisis data penelitian setelah mendapatkan perlakuan bimbingan belajar dengan media audio visual, menunjukkan adanya pengaruh positif dan signifikan dari bimbingan belajar dengan media audio visual terhadap kreativitas belajar siswa. Peningkatan rata-rata kreativitas belajar siswa kelas X MAN I Demak dari sebelum treatment adalah $72,63 \%$ dan sesudah treatment sebesar $91,7 \%$. Dan sisanya $19,07 \%$ ditentukan oleh faktor lain yaitu kondisi psikologi dan kondisi lingkungan. Hal ini diperkuat dengan hasil uji-t dimana $t_{\text {hitung }}=$ 6,23 dan $t_{\text {tabel }}=2,04$ menunjukkan bahwa nilai $t_{\text {hitung }}>t_{\text {tabel }}$ dengan taraf signifikan 5\%. Dengan demikian dapat disimpulkan bahwa bimbingan belajar dengan media audio visual berpengaruh terhadap kreativitas belajar siswa.

Berdasarkan penelitian yang dilakukan peneliti di atas menunjukkan bahwa penggunaan media audio-visual sebagai penunjang sebuah bimbingan kelompok mampu meningkatkan kreativitas siswa dalam suatu pembelajaran. Hal tersebut dibuktikan dengan hasil rata-rata kreativitas siswa yang mengalami peningkatan dari pretest (sebelum treatment) sebesar $72,63 \%$ dan posttest (setelah treatment) sebesar $91,7 \%$. Sehingga dari penelitian tersebut dapat disimpulkan bahwa penggunaan media audio-visual dapat meningkatkan kreativitas siswa dalam belajar.

Berdasarkan ketiga penelitian yang relevan di atas menunjukkan kesamaan hasil bahwa penggunaan media audio-visual dalam suatu pembelajaran dapat menunjang ketercapaian tujuan pembelajaran dengan optimal dan efektif (bandingkan dengan Adhini Virgiana dan Wasitohadi, 2016).

\section{Simpulan}

Berdasarkan hasil penelitian dapat disimpulkan bahwa penggunaan media audio visual efektif terhadap keterampilan menulis puisi siswa kelas V SD N 2 Mororejo Kendal. Hal ini dibuktikan dengan uji hipotesis yang telah dilakukan peneliti. Hipotesis yang dirumuskan ialah jika 
Keefektifan Media Audio Visual Sebagai Kreativitas Guru Sekolah Dasar Terhadap Keterampilan Menulis Puisi Siswa (Arum Tri Lestari, Mudzanatun, Aries Tika Damayani)

$t_{\text {hitung }}>t_{\text {tabel }}$ maka $\mathrm{H}_{0}$ ditolak dan Ha diterima, artinya penggunaan media audio visual terhadap keterampilan menulis puisi efektif. Berdasarkan uji t dari $\mathrm{N}=25$ dan taraf signifikan $=0,5$ diperoleh $\mathrm{t}_{\text {hitung }}=6,170$ dan $\mathrm{t}_{\text {tabel }}=2,064$. Berdasarkan perolehan data tersebut menunjukkan bahwa $\mathrm{t}_{\text {hitung }}>\mathrm{t}_{\text {tabel }}$ yaitu 6,170 > 2,064, maka $\mathrm{H}_{0}$ ditolak dan Ha diterima. Artinya uji-t signifikan. Selain itu, berdasarkan hasil nilai pretest dan posttest juga menunjukkan bahwa ada peningkatan dari rata-rata nilai pretest sebesar 69,6 menjadi 81,2 yang merupakan hasil rata-rata nilai posttest sebesar 11,6. Sehingga dapat disimpulkan bahwa penggunaan media audio visual efektif terhadap keterampilan menulis puisi siswa. Jadi, kreativitas guru melalui media audio visual dapat meningkatkan keterampilan menulis puisi siswa SD N 2 Mororejo Kendal.

\section{Saran}

Setelah melakukan penelitian, peneliti memberi saran sebagai berikut:

1. Hendaknya guru sering melakukan inovasi dan variasi pembelajaran agar siswa tidak mudah jenuh dan bosan ketika kegiatan pembelajaran berlangsung. Sehingga siswa akan memperhatikan dan antusias dalam belajar. Misalkan dengan menggunakan alat-alat maupun fasilitas yang dimiliki sekolah sebagai alat peraga atau media pembelajaran yang dapat menunjang pembelajaran sesuai materi pelajaran yang dipelajari.

2. Ketika guru hendak menggunakan media berupa audio visual, selain menyiapkan alat penunjang yang dibutuhkan, guru juga perlu mengatur pencahayaan ruang kelas agar media yang diproyeksikan di depan kelas tetap terlihat oleh seluruh siswa. Ejaan dan ukuran huruf dalam media juga disesuaikan dengan luas kelas dan banyak siswa yang akan melihat agar siswa tertarik dan nyaman dengan media yang digunakan guru. Sehingga akan menunjang tercapainya tujuan pembelajaran dengan optimal.

\section{DAFTAR PUSTAKA}

Adhini Virgiana dan Wasitohadi, 2016. Efektivitas Model Problem Based Learning Berbantuan Media Audio Visual Ditinjau dari Hasil Belajar IPA Siswa Kelas 5 SDN 1 Gadu Sambong - Blora Semester 2 Tahun 2014/2015. Scholaria, Vol. 6 No. 2, Mei 2016: 100 118

Anggraini, Dian, dkk. 2013. Peningkatan Kemampuan Menulis Puisi dengan Menggunakan Metode Concept Sentence.http://jurnal.fkip.uns.ac.id. Diakses 24 Oktober 2016

Arikunto, Suharsimi. 2010. Prosedur Penelitian: Suatu Pendekatan Praktik. Jakarta: Rineka Cipta

Arsyad, Azhar. 2014. Media Pembelajaran. Jakarta: Raja Grafindo Persada

Azmussya'ni, dkk. 2014. Peningkatan keterampilan menulis menggunakan pendektan proses dengan media gambar di SD N 3 Sakra. http://journal.uny.ac.id. Diakses 17 Januari 2016.

Departemen Pendidikan Nasional. 2004. Kurikulum 2004 dan Kurikulum Tingkat Satuan Pendidikan (KTSP) 2004. Jakarta: Departemen Pendidikan Nasional.

Haryoko, Sapto. 2009. Efektivitas Pemanfaatan Media Audio-Visual sebagai alternatif optimalisasi model pembelajaran. http://jurnal.uny.ac.id/. Diakses pada 24 Oktober 2016.

Retti, Sufia, dkk. 2013. Peningkatan Keterampilan Menulis Puisi Melalui Prinsip-prinsip Sugestologi Siswa Kelas VII.1 SMP N 4 VII Koto Sungai Sarik Kabupaten Padang Pariaman. http://ejournal.unp.ac.id. Diakses pada 24 Oktober 2016.

Sadiman, Arief S, dkk. 2014. Media Pendidikan Pengertian, Pengembangan, dan Pemanfaatannya. Jakarta: Rajawali Pers

Sanaky, Hujair AH. 2013. Media Pembelajaran Interaktif-Inovatif. Yogyakarta: Kaukaba Dipantara

Subekti, Ervina Eka. 2015. Buku Pegangan Kuliah: Statistika 2. Semarang: cetakan upgris

Sudjana, Nana. 2005. Metode Statistika: Edisi ke-6. Bandung: Tarsito 
Sugiyono. 2010. Metode Penelitian Pendidikan. Bandung: Alfabeta

Sulistyorini, Dwi. 2010. Peningkatan KeterampilanMenulis Puisi dengan Media Gambar Pada Siswa Kelas V SDN Sawojajar V Kota Malang.http://jurnalpendidikaninside. blogspot.com. Diakses 24 Oktober 2016.

Syamsi, Kastam. 2012. Model Perangkat Pembelajaran Menulis Berdasarkan Pendekatan Proses Genre Bagi Siswa SMP. http://eprints.uny.ac.id. Diakses 10 Desember 2016.

\section{BIODATA DIRI}

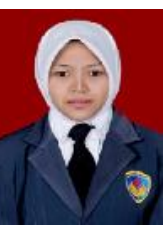

\section{Arum Tri Lestari}

Kelahiran Jepara pada tanggal 6 September 1995. Penulis menyelesaikan pendidikan terakhir dari prodi PGSD, Fakultas Ilmu Pendidikan, Universitas PGRI Semarang pada bulan Mei 2017 dengan gelar Sarjana Pendidikan. Pengalaman bekerja pernah menjadi tentor privat siswa sekolah dasar. 